\title{
Transplant Recipient
}

National Cancer Institute

\section{Source}

National Cancer Institute. Transplant Recipient. NCI Thesaurus. Code C159659.

An individual receiving a transplant. 